International Journal of English Language Studies (IJELS)

ISSN: 2707-7578

DOI: 10.32996/jweep

Website: https://al-kindipublisher.com/index.php/ijels

\title{
Efficacy of Scan Attendance Manager Application Using Quick Response Code in Dagohoy National High School, Bohol, Philippines
}

Jeson Jacinto Galgo

Senior High School Teacher II, Dagohoy National High School, Philippines

Corresponding Author: Jeson J. Galgo, E-mail: galgo.jeson123@gmail.com

ARTICLE INFO

Received: September 21, 2020

Accepted: October 16, 2020

Volume: 2

Issue: 4

DOI: 10.32996/ijes.2020.2.4.1

\section{KEYWORDS}

Scan Attendance Manager

Application, QR Code, Efficacy, Reliability, Efficiency, Accuracy, Usability, Security

\section{ABSTRACT}

This study primarily aimed to assess the efficacy of Scan Attendance Manager Application using Quick Response Code as perceived by the teachers in Dagohoy National High School, Dagohoy, Bohol, Philippines, School Year 2019-2020. It utilized DescriptiveComparative research design through survey method. It was concluded that the Scan Attendance Manager is a reliable application wherein teachers could conveniently use to monitor class attendance by simply scanning the QR code embedded to each student's ID. As expected, this application provides efficient data output from detecting absent students to generating reports; thus, it is advisable to use. As all teacher-respondents strongly agree, there is nothing to worry about generating the reports since the data produced by the SAM application is definitely accurate. It was also concluded that the Scan Attendance Manager app is not only useful for classroom attendance; it can also be used to different kind of activities considering that there will be attendance to monitor. Moreover, the attendance data report was securely stored in the SAM database, and the teachers need nothing to worry about confidentiality since they are the only ones who have access. There is a significant difference between the weighted average class attendance percentage of the months before and after using the SAM app. It further signifies that the attendance of the class after the teachers have utilized the SAM application had evidently shown significant improvement; thus the Scan Attendance Manager Application using Quick Response Code is useful not just by providing convenience to teachers, but importantly it virtually eliminates absences. There is a significant variance among the five classifications of the Efficacy of the Scan Attendance Manager App as perceived by the teachers. Among the five classifications, teachers have extensively perceived the efficient output that Scan Attendance Manager could provide in terms of its general function in monitoring class attendance.

\section{Introduction}

Class attendance is essential because it is believed that learners are more likely to succeed in academics when they reported to school regularly. It is hard for learners to develop their skills and make progress in the class if lots of them are not attending school (GreatSchools Staff, 2011). Another reason why students need always to attend classes is the quality of learning they may get. Learners who regularly attend their classes may have advance knowledge and skills compared to those who did not.

Class attendance matters. It is one of the most significant indicators of school achievement. Students who go to class usually improve their chances of being academically useful. There are explicit exemptions to the two sides of the standard. There are students deemed academically successful who also have attendance issues and a few students who

K C AL-KINDI CENTER R D FOR RESEARCH AND R DEVELOPMENT Your gateway to world-class research
Published by Al-KindiCenter for Research and Development. Copyright (c) the author(s). This is an open access article under CC BY license (https://creativecommons.org/licenses/by/4.0/) 
academically struggle who are always present. However, according to Meador, D. (2017) that in most cases, strong attendance correlates with academic success, and low attendance correlates with academic struggles. In other words, when students are not attending classes, learning would possibly be compromised.

From industrial society, the human is in the conversion to an information society. The procedure of deriving in this transition and advancement can make people struggle in embracing changes. Nevertheless, the innovation of technology brings importance and advancement in human lives. This innovation could be a great help and give light to students and teachers when it will be applied inside the classroom, particularly in monitoring class attendance.

One of the most useful gadgets anyone is using nowadays is the smartphone. There are lots of mobile applications that a teacher could use to monitor class attendance, and one of them is the Quick Response Code (QR Code), which is proven effective by some teachers who were able to utilize it. The QR code is very efficient for students and teachers to make their tasks and paperwork many ways more comfortable because it is easy to handle just by scanning one time, and it is already recorded.

The researcher as a secondary teacher affiliated in Dagohoy National High School has always observed that almost all teachers were utilizing the traditional way of checking the class attendance; either the teacher himself manually check the attendance through the roll-call method, or assigning a student class monitor to do the checking of attendance. As experienced, this traditional paper-pen checking of attendance is aside from typically time-consuming and burden, it is prone to have a glitched report as the teacher may mistakenly input the wrong data, or the assigned class monitor may be a bias of checking the attendance.

The researcher himself has tried to use different mobile applications useful for the learning-teaching process in the school. Still, the Scan Attendance Manager application (SAM App) gives more efficient result in terms of monitoring class attendance. This application is a free android application released by ShmoopySoft Company that anyone could download and install from the google play store. This application will not just scan the QR Code ID of the students to record attendance, but one of its most exciting and very useful features is that it sends SMS report to parents with the real-time attendance of the student. In such a way, teachers' class monitoring will become much more comfortable because parents will already be the ones to do a followup on the progress made by the students.

The premises mentioned above motivate the researcher to conduct a study about the effectiveness of utilizing QR Code in monitoring class attendance in lieu with the traditional paper-pen method. The researcher believed that this study would help other teachers, especially the classroom advisers, to embrace innovation in monitoring their students' attendance more efficiently. This study primarily aimed to evaluate the efficacy of Scan Attendance Manager Application using Quick Response Code as perceived by the teachers in Dagohoy National High School, Dagohoy, Bohol, Philippines, School Year $2019-2020$. Specifically, this study is guided with the following objectives: To evaluate the efficacy of Scan Attendance Manager app as perceived by the teachers in terms of reliability, efficiency, accuracy, usability, and security; to identify the level of class attendance percentage average on the months before and after using the SAM app; significant difference on the weighted average class attendance percentage between the months before and after using the SAM app; and significant variance among the five classifications of the Efficacy of Scan Attendance Manager App as perceived by the teachers.

\section{Literature Review}

As suggested by Self-determination theory, people are motivated to develop by three innate and universal psychological needs; this suggests that people can become self-determined when their needs for competence, connection, and autonomy are fulfilled (Cherry, K., 2019). Self-determined learners are more likely to feel motivated to achieve. There are things that teachers can do to help students foster a sense of self-determination and intrinsic motivation: Providing unexpected positive feedback when students perform well can help improve competence; and Avoiding excessive external rewards for actions students already enjoy can help improve internal motivation.

Another theory that supports this study is the Theory of Work Adjustment which also referred as the Person-Environment Correspondence Theory states that the more closely a person's abilities (skills, knowledge, experience, attitude, behaviours, etc.) correspond with the requirements of the role of the organization, the more they will perform the job properly and be perceived as satisfactory by the employer (Theory of Work Adjustment, n.d.). 
Stipulated in the Batas Pambansa Blg. 232 or an act providing for the establishment and maintenance of an integrated system of education; the State shall establish and maintain a complete, adequate, and integrated system of knowledge relevant to the goals of national development. Toward this end, the government shall ensure, within the context of a free and democratic system, the maximum contribution of the education.

Republic Act 672 or shall be known as the "Government Assistance to Students and Teachers in Private Education Act." It is proclaimed policy of the State in conformity with the mandate of the Constitution, to promote and make quality education accessible to all Filipino citizens. The State, at this moment, acknowledged the complementary roles of public and private educational organizations in the educational system and the invaluable contribution made by the private schools. For these reasons, the State shall give the mechanisms to improve quality in private education by maximizing the use of existing resources of private education, recognizing in the process the government responsibility to provide primary elementary and secondary school as having priority over its function to provide for higher education.

Chronic absenteeism will prompt students to frustration, because the more they miss, the harder it becomes to catch up. Consequently, the student gives up altogether, putting them on a path towards being a high school dropout. Chronic absenteeism is a critical indicator that a student will drop out, this makes it even more critical to find early intervention strategies to prevent attendance from ever becoming an issue (Meador, D., 2017).

Furthermore, Meador, D. (2017) said that improving school attendance can prove to be a challenging endeavour. Schools often have limited direct control in this field. Most of the responsibility falls on the learner's parents or guardians, especially the elementary-aged ones. Lots of parents simply do not grasp how essential attendance is. Furthermore, they do not understand the hidden message that they are disseminating to their children by allowing them to absent from school. Lastly, they do not realize that they are not only setting their children up to fail in school but also life.

A 2008 study conducted by the Rodel Community Scholars at Arizona State University that tracked students from kindergarten through high school found that dropout patterns were linked with low attendance, beginning in kindergarten. Gregory Hickman, director of the Rodel Community Scholars program and former director of the Arizona Dropout Initiative, notes they discovered that as early as kindergarten, behavioural differences are apparent between those who go on to graduate and those who drop out, with dropouts missing an average of 124 days by eighth grade (GreatSchools Staff, 2011).

Woods, R. (2015) stated that the best practices to improve attendance and degrade truancy had been identified: cooperation, use of incentives and sanctions, family involvement, the founding of a supportive context, and assessment of the program. Effective programs will present the elements of best practices and the 15 effective methods. The collection of resources provided may help improve existing programs or facilitate the establishment of new programs to improve student attendance and reduce truancy.

Student's attendance is one of the most critical steps to a student's academic performance. Learners' absenteeism is defined as a student missing 20 or more school days within one academic school year. When students miss school consistently, they are identified as chronically absent. The main causes that impact student attendance in an urban elementary school district from parents' perspectives. For a qualitative method, interviews were done with parents of learners who attended schools within a city school district. They gave insights into both the obstacles and solutions that families face regarding attendance (Roshon, B., 2015).

Students with engaged parents report fewer school days missed in general. Two-way communication between guardians and educators commits students to daily attendance and raises class participation levels (Epstein, J.L. \& Sheldon, S.B., 2004). Family engagement is an integral part of reducing school absenteeism, and schools need to collaborate with families to improve student attendance (Epstein, J.L. \& Sheldon, S.B., 2002).

An attendance monitoring system serves as a time log that is set up as a computerized database. An attendance monitoring system maintains a daily time record of a person's arrival and departure from work or school. Due to the lack of security in schools, students are not afraid to cut their classes or sometimes go home late as their guardians are not informed of their 
schedules (Lucido, 2014). According to the study of Farhan, A. (2015) entitled "Students Attendance Monitoring", QR code (Quick Response Code) is a much convenient way to check the attendance. Students were provided tags that the checker must scan on it and it is already recorded.

As featured by Molina, C.J. (2018) in his blog at inquirer.net, according to teacher Michael Angelo Maleriado of Imus City, Cavite, who teaches contact centre services under the Technology and Livelihood Education (TLE) subject, that using QR codes are not only time-saving and easier for data access since it is done digitally, it is also cost-effective since it is a green initiative that involves minimal use of paper.

With the aid of an attendance system, schools and other organizations can save time and money. When talking about an attendance management system, it is not specifically only for schools or companies. It can be used everywhere where people in a large number of works. Apart from saving time, this system also helps in saving money of the organization, which was otherwise lost in monitoring, and updating information (Gayatri, R., n.d.).

As stated in the study of Maleriado, M.A.C. and Carreon, J. R. (2018) entitled "The features of Quick Response (QR) Code as an Attendance Monitoring System: Its Acceptability and Implications", that QR Code as attendance monitoring system was very highly acceptable based on reliability, efficiency, accuracy, usability, while highly acceptable when it comes to security and confidentiality. The perception of the participants implies that QR code as attendance checker was environment-friendly, costeffective, user-friendly, innovative, very fast, and readable codes.

\section{Methodology}

\subsection{Research Design}

This study has utilized Descriptive-Comparative research design. Descriptive in the sense that the researcher tends to describe the efficacy of Scan Attendance Manager app as perceived by the teachers in Dagohoy National High School, for the school year 2019-2020. Comparative on the other hand, because it also sought to determine if there's a significant difference on the class attendance percentage average between the months before and after using the SAM App; also this study tends to evaluate if there's significant variance among the five categories of the efficacy of the SAM App as perceived by the teachers.

\subsection{Research Instrument}

The researcher has utilized a questionnaire that was patterned after the study of Maleriado, M.A.C. and Carreon, J. R. (2018) entitled "The features of Quick Response (QR) Code as an Attendance Monitoring System: Its Acceptability and Implications" to measure the problems herein stated. The instrument was classified into two sections; the first part contains items that evaluate teachers' level of acceptability in using QR Code Scan Attendance Manager App in terms of the following criteria: reliability, efficiency, accuracy, usability, and security. The second part contains items that correspond to teachers' views about the efficacy of Scan Attendance Manager App.

\subsection{Statistical Treatment}

Upon retrieval, the data gathered were tabulated, treated, analyzed, interpreted, and reported. The weighted mean score was used to describe the level of acceptability of the teachers in using the SAM app, and the efficacy of the said application as perceived by the teachers. After getting the mean, the data were interpreted using a scale. T-test of two independent samples was used to evaluate if there's a significant difference in the class attendance percentage average between the months before and after using the SAM app. Lastly, One-Way ANOVA (Analysis of Variance) was also used to analyze the significant variance among the five categories of the efficacy of Scan Attendance Manager Application as perceived by the teachers.

\section{Results and Discussion}

Table 1. Efficacy of the Scan Attendance Manager App as perceived by the Teachers.

\begin{tabular}{c|c|c}
\hline \hline EFFICACY OF SCAN ATTTENDANCE MANAGER APPLICATION & $\begin{array}{c}\text { Weighted } \\
\text { Mean }\end{array}$ & $\begin{array}{c}\text { Descriptive } \\
\text { Interpretation }\end{array}$ \\
\hline A. RELIABILITY & & \\
\hline $\begin{array}{l}\text { 1. There is no trouble encountered while using the QR Attendance / } \\
\text { SAM app. }\end{array}$ & 3.58 & Strongly Agree \\
\hline
\end{tabular}




\begin{tabular}{|c|c|c|}
\hline $\begin{array}{l}\text { 2. The data is running and consistent all the time and reduces the } \\
\text { potential for data redundancy. }\end{array}$ & 3.44 & Strongly Agree \\
\hline $\begin{array}{l}\text { 3. Users can review the entire scanned files at the mobile phone } \\
\text { and/or in an excel format. }\end{array}$ & 3.46 & Strongly Agree \\
\hline COMPOSITE MEAN & 3.49 & Strongly Agree \\
\hline \multicolumn{3}{|l|}{ B. EFFICIENCY } \\
\hline $\begin{array}{l}\text { 1. The SAM database interface provides a history and current report } \\
\text { on attendance. }\end{array}$ & 3.56 & Strongly Agree \\
\hline $\begin{array}{l}\text { 2. It's paperless, and it generates reports even without the need of } \\
\text { internet. }\end{array}$ & 3.80 & Strongly Agree \\
\hline 3. It proficiently detects absenteeism on the class. & 3.66 & Strongly Agree \\
\hline COMPOSITE MEAN & 3.67 & Strongly Agree \\
\hline \multicolumn{3}{|l|}{ C. ACCURACY } \\
\hline $\begin{array}{l}\text { 1. The content of the program is very organized in a coherent } \\
\text { manner. }\end{array}$ & 3.44 & Strongly Agree \\
\hline $\begin{array}{l}\text { 2. The SAM application shows real-time attendance of the students } \\
\text { provided with the accurate time upon arrival and/or departure. }\end{array}$ & 3.72 & Strongly Agree \\
\hline $\begin{array}{l}\text { 3. The data entered on the SAM database interface is accurate, } \\
\text { valid, consistent, and up to date. }\end{array}$ & 3.50 & Strongly Agree \\
\hline COMPOSITE MEAN & 3.55 & Strongly Agree \\
\hline \multicolumn{3}{|l|}{ D. USABILITY } \\
\hline $\begin{array}{l}\text { 1. The user interface shows the correct labeling and essential } \\
\text { information of the program; color themes of the application are } \\
\text { also pleasing to the eyes and are not distressing. }\end{array}$ & 3.44 & Strongly Agree \\
\hline $\begin{array}{l}\text { 2. The SAM App is not only useful for class attendance purposes, } \\
\text { but it is also applicable to any organization. }\end{array}$ & 3.44 & Strongly Agree \\
\hline $\begin{array}{l}\text { 3. It shows statistical reports on attendance daily, weekly, monthly, } \\
\text { and yearly. }\end{array}$ & 3.66 & Strongly Agree \\
\hline COMPOSITE MEAN & 3.51 & Strongly Agree \\
\hline \multicolumn{3}{|l|}{ E. SECURITY } \\
\hline $\begin{array}{l}\text { 1. The program can only be accessed by the teacher who utilized } \\
\text { the system using the QR Code Scan Attendance Manager App } \\
\text { installed on the smartphone. }\end{array}$ & 3.34 & Strongly Agree \\
\hline $\begin{array}{l}\text { 2. The data on students' attendance was protected through the } \\
\text { backup database stored online and offline. }\end{array}$ & 3.44 & Strongly Agree \\
\hline $\begin{array}{l}\text { 3. Parents' contact numbers were embedded on the application } \\
\text { wherein every time the students scan their QR Codes; they } \\
\text { receive a real-time notification. }\end{array}$ & 3.56 & Strongly Agree \\
\hline COMPOSITE MEAN & 3.45 & Strongly Agree \\
\hline GRAND COMPOSITE MEAN & 3.54 & Strongly Agree \\
\hline
\end{tabular}


Table 1 presents the efficacy of Scan Attendance Manager App as perceived by the teachers. It was depicted from the table that teachers as users of the application strongly agree that all five classifications are accurate as to the efficacy of Scan Attendance Manager.

With regards to reliability, teachers strongly agree with the statement that there is no trouble encountered while using the QR Attendance / SAM app as it garnered the highest weighted mean of 3.58. On the other hand, they also strongly agree that users can review the entire scanned files at the mobile phone and in an excel format, and the data is running and consistent all the time and reduces the potential for data redundancy, as these statements obtained weighted means of 3.46 and 3.44 respectively. The result further implies that the Scan Attendance Manager is a reliable application wherein teachers could conveniently use to monitor class attendance by simply scanning the QR code embedded to each student's ID. This result is supported by the study of Farhan, A. (2015) entitled "Students Attendance Monitoring", where he stressed that QR code (Quick Response Code) is much convenient way to check the attendance.

As to efficiency, it can be seen from the table that the second statement got the highest weighted mean of 3.80 which means teachers strongly agree that by the use of SAM app, it's paperless. It generates reports even without the need of internet. Furthermore, they also strongly agree that SAM app proficiently detects absenteeism on the class, and its database interface provides a history and current report on attendance, as these statements got weighted means of 3.66 and 3.56 respectively. The result signifies that Scan Attendance Manager (SAM) as expected, provides efficient data output from detecting absent students to generating reports, thus it is advisable to use. As also mentioned, SAM application is a cost-effective strategy, as it doesn't need paper to check the attendance. Molina, C.J. (2018) supports this result wherein he featured in his blog at inquirer.net teacher Michael Angelo Maleriado of Imus City, Cavite, teaches contact centre services under the Technology and Livelihood Education (TLE) subject, who further noted that using QR codes are not only time-saving and easier for data access since it is done digitally, it is also cost-effective since it is a green initiative that involves minimal use of paper.

In terms of accuracy, it was shown from the table, that the teachers, with the highest weighted mean of 3.72 , strongly agree that the SAM application shows real-time attendance of the students provided with the accurate time upon arrival and departure. They also strongly agree that the data entered on the SAM database interface is accurate, valid, consistent, and up to date, and the content of the program is very organized coherently with weighted means of 3.50 and 3.44 respectively. The result only implies that there is nothing to worry about generating the reports since the data produced by the SAM application is definitely accurate.

As to usability, the third statement prevailed to have the highest weighted mean of 3.66 which means that the teachers strongly agree that SAM app shows statistical reports on attendance daily, weekly, monthly, and yearly. On the other hand, they also strongly agree that the user interface shows the correct labelling and essential information of the program; colour themes of the application are also pleasing to the eyes and are not distressing, and the SAM App is not only useful for class attendance purposes, but it is also applicable to any organization; both of these statements got a weighted mean of 3.44. The result simply means that the Scan Attendance Manager app is not only useful for classroom attendance; it can also be used to different kind of activities considering that there will be an attendant to monitor.

In terms of security, with the highest weighted mean of 3.56, teachers strongly agree that parents' contact numbers were embedded on the application wherein every time the students scan their QR Codes; they receive a real-time notification. Moreover, the second statement has obtained a weighted mean of 3.44 which means the teachers strongly agree that the data on students' attendance was protected through the backup database stored online and offline. Finally, teachers also strongly agree that the program can only be accessed by the teacher who utilized the system using the QR Code Scan Attendance Manager App installed on the smartphone with a weighted mean of 3.34. The result simply signifies that the attendance data report was securely stored in the SAM database, and the teachers need nothing to worry about confidentiality since they are the only ones who have access. This application does not only give security to the data report, but it importantly gives security to students, as their parents are always get notified on their real-time attendance; thus, students are closely monitored not just by the teachers but also by their parents. This result addresses the scenario stressed by Lucido (2014) that due to the lack of security in schools, students are not afraid to cut their classes or sometimes go home late as their guardians are not informed of their schedules. 
The result, in general, is supported by Maleriado, M.A.C. and Carreon, J. R. (2018) in their study entitled "The features of Quick Response (QR) Code as an Attendance Monitoring System: Its Acceptability and Implications", wherein they claim that the Quick Response Code as attendance monitoring system was generally very highly acceptable in terms of reliability, efficiency, accuracy, usability, while highly acceptable in terms of security and confidentiality.

Table 2.1. Data of the Class Attendance Percentage Average on the months before and after using the SAM application.

\begin{tabular}{|c|c|c|c|c|c|c|c|c|c|c|c|c|c|c|}
\hline \multirow[b]{2}{*}{$\begin{array}{c}\text { Class } \\
\mathrm{n}=50\end{array}$} & \multicolumn{5}{|c|}{ Before using the SAM Application } & \multirow[b]{2}{*}{ AVG } & \multirow[b]{2}{*}{ DI } & \multicolumn{5}{|c|}{ After Using the SAM Application } & \multirow[b]{2}{*}{ AVG } & \multirow[b]{2}{*}{ DI } \\
\hline & $\begin{array}{l}\text { June } \\
2019\end{array}$ & $\begin{array}{l}\text { July } \\
2019\end{array}$ & $\begin{array}{l}\text { Aug. } \\
2019\end{array}$ & $\begin{array}{c}\text { Sept } \\
\cdot \cdot \\
2019\end{array}$ & $\begin{array}{l}\text { Oct. } \\
2019\end{array}$ & & & $\begin{array}{l}\text { Nov. } \\
2019\end{array}$ & $\begin{array}{l}\text { Dec. } \\
2019\end{array}$ & $\begin{array}{l}\text { Jan. } \\
2020\end{array}$ & $\begin{array}{l}\text { Feb. } \\
2020\end{array}$ & $\begin{array}{c}\text { Marc } \\
h \\
2020\end{array}$ & & \\
\hline 1 & 94.15 & $\begin{array}{c}90.8 \\
5\end{array}$ & $\begin{array}{c}89.8 \\
1\end{array}$ & $\begin{array}{c}80.1 \\
5\end{array}$ & $\begin{array}{c}81.0 \\
0\end{array}$ & $\begin{array}{c}87.1 \\
9\end{array}$ & VS & 95.16 & 98.51 & 99.98 & $\begin{array}{c}100.0 \\
0\end{array}$ & $\begin{array}{c}100.0 \\
0\end{array}$ & 98.73 & $\mathrm{O}$ \\
\hline 2 & 95.98 & $\begin{array}{c}94.0 \\
0\end{array}$ & $\begin{array}{c}89.8 \\
4\end{array}$ & $\begin{array}{c}84.0 \\
5\end{array}$ & $\begin{array}{c}80.6 \\
5\end{array}$ & $\begin{array}{c}88.9 \\
0\end{array}$ & VS & 94.00 & 94.85 & 99.95 & $\begin{array}{c}100.0 \\
0\end{array}$ & 99.60 & 97.68 & $\mathrm{O}$ \\
\hline 3 & 96.51 & $\begin{array}{c}90.8 \\
5 \\
\end{array}$ & $\begin{array}{c}84.1 \\
5 \\
\end{array}$ & $\begin{array}{c}80.6 \\
5 \\
\end{array}$ & $\begin{array}{c}82.1 \\
5 \\
\end{array}$ & $\begin{array}{c}86.8 \\
6 \\
\end{array}$ & VS & 99.65 & 99.75 & $\begin{array}{c}100.0 \\
0\end{array}$ & $\begin{array}{c}100.0 \\
0 \\
\end{array}$ & $\begin{array}{c}100.0 \\
0\end{array}$ & 99.88 & $\mathrm{O}$ \\
\hline 4 & 98.00 & $\begin{array}{c}95.6 \\
5 \\
\end{array}$ & $\begin{array}{c}93.8 \\
5 \\
\end{array}$ & $\begin{array}{c}95.0 \\
0 \\
\end{array}$ & $\begin{array}{c}89.6 \\
5 \\
\end{array}$ & $\begin{array}{c}94.4 \\
3 \\
\end{array}$ & 0 & 96.84 & 98.90 & $\begin{array}{c}100.0 \\
0\end{array}$ & 99.89 & $\begin{array}{c}100.0 \\
0\end{array}$ & 99.13 & $\mathrm{O}$ \\
\hline 5 & 97.00 & $\begin{array}{c}90.5 \\
1 \\
\end{array}$ & $\begin{array}{c}85.0 \\
2 \\
\end{array}$ & $\begin{array}{c}82.1 \\
5 \\
\end{array}$ & $\begin{array}{c}83.1 \\
5 \\
\end{array}$ & $\begin{array}{c}87.5 \\
7 \\
\end{array}$ & VS & 98.65 & 99.65 & $\begin{array}{c}100.0 \\
0\end{array}$ & $\begin{array}{c}100.0 \\
0\end{array}$ & $\begin{array}{c}100.0 \\
0\end{array}$ & 99.66 & $\mathrm{O}$ \\
\hline 6 & 97.25 & $\begin{array}{c}96.2 \\
3\end{array}$ & $\begin{array}{c}94.5 \\
1\end{array}$ & $\begin{array}{c}91.2 \\
3\end{array}$ & $\begin{array}{c}90.0 \\
0\end{array}$ & $\begin{array}{c}93.8 \\
4\end{array}$ & 0 & 99.00 & 99.65 & $\begin{array}{c}100.0 \\
0\end{array}$ & 99.84 & $\begin{array}{c}100.0 \\
0\end{array}$ & 99.70 & $\mathrm{O}$ \\
\hline 7 & 95.16 & $\begin{array}{c}94.6 \\
5\end{array}$ & $\begin{array}{c}89.1 \\
5\end{array}$ & $\begin{array}{c}84.0 \\
5\end{array}$ & $\begin{array}{c}85.6 \\
5\end{array}$ & $\begin{array}{c}89.7 \\
3\end{array}$ & VS & 99.94 & $\begin{array}{c}100.0 \\
0\end{array}$ & $\begin{array}{c}100.0 \\
0\end{array}$ & $\begin{array}{c}100.0 \\
0\end{array}$ & $\begin{array}{c}100.0 \\
0\end{array}$ & 99.99 & $\mathrm{O}$ \\
\hline 8 & 98.43 & $\begin{array}{c}97.0 \\
0\end{array}$ & $\begin{array}{c}90.3 \\
5\end{array}$ & $\begin{array}{c}90.0 \\
0\end{array}$ & $\begin{array}{c}85.0 \\
0\end{array}$ & $\begin{array}{c}92.1 \\
6\end{array}$ & 0 & $\begin{array}{c}100.0 \\
0\end{array}$ & 99.69 & 99.89 & $\begin{array}{c}100.0 \\
0\end{array}$ & $\begin{array}{c}100.0 \\
0\end{array}$ & 99.92 & 0 \\
\hline 9 & 96.85 & $\begin{array}{c}91.0 \\
5\end{array}$ & $\begin{array}{c}85.1 \\
5\end{array}$ & $\begin{array}{c}80.1 \\
5\end{array}$ & $\begin{array}{c}80.1 \\
0\end{array}$ & $\begin{array}{c}86.6 \\
6\end{array}$ & VS & 98.15 & 99.90 & $\begin{array}{c}100.0 \\
0\end{array}$ & $\begin{array}{c}100.0 \\
0\end{array}$ & $\begin{array}{c}100.0 \\
0\end{array}$ & 99.61 & 0 \\
\hline 10 & 94.85 & $\begin{array}{c}90.8 \\
4\end{array}$ & $\begin{array}{c}84.1 \\
5\end{array}$ & $\begin{array}{c}86.7 \\
5\end{array}$ & $\begin{array}{c}85.8 \\
1\end{array}$ & $\begin{array}{c}88.4 \\
8\end{array}$ & VS & 99.65 & 98.95 & $\begin{array}{c}100.0 \\
0\end{array}$ & 99.65 & $\begin{array}{c}100.0 \\
0\end{array}$ & 99.65 & 0 \\
\hline 11 & 97.78 & $\begin{array}{c}94.0 \\
0 \\
\end{array}$ & $\begin{array}{c}90.6 \\
4\end{array}$ & $\begin{array}{c}86.6 \\
4\end{array}$ & $\begin{array}{c}85.0 \\
0\end{array}$ & $\begin{array}{c}90.8 \\
1\end{array}$ & 0 & $\begin{array}{c}100.0 \\
0\end{array}$ & 99.94 & 99.98 & $\begin{array}{c}100.0 \\
0 \\
\end{array}$ & $\begin{array}{c}100.0 \\
0\end{array}$ & 99.98 & 0 \\
\hline 12 & 95.84 & $\begin{array}{c}90.8 \\
5\end{array}$ & $\begin{array}{c}84.8 \\
5\end{array}$ & $\begin{array}{c}80.5 \\
1\end{array}$ & $\begin{array}{c}80.8 \\
5\end{array}$ & $\begin{array}{c}86.5 \\
8\end{array}$ & VS & $\begin{array}{c}100.0 \\
0\end{array}$ & 99.68 & $\begin{array}{c}100.0 \\
0\end{array}$ & 98.94 & $\begin{array}{c}100.0 \\
0\end{array}$ & 99.72 & 0 \\
\hline 13 & $\begin{array}{c}100.0 \\
0\end{array}$ & $\begin{array}{c}95.6 \\
4\end{array}$ & $\begin{array}{c}90.8 \\
1\end{array}$ & $\begin{array}{c}89.5 \\
2\end{array}$ & $\begin{array}{c}83.2 \\
5\end{array}$ & $\begin{array}{c}91.8 \\
4\end{array}$ & 0 & 99.68 & 99.94 & $\begin{array}{c}100.0 \\
0\end{array}$ & $\begin{array}{c}100.0 \\
0\end{array}$ & $\begin{array}{c}100.0 \\
0\end{array}$ & 99.92 & 0 \\
\hline 14 & 99.00 & $\begin{array}{c}90.6 \\
4 \\
\end{array}$ & $\begin{array}{c}86.6 \\
0 \\
\end{array}$ & $\begin{array}{c}84.8 \\
5 \\
\end{array}$ & $\begin{array}{c}85.0 \\
0 \\
\end{array}$ & $\begin{array}{c}89.2 \\
2 \\
\end{array}$ & VS & 99.68 & $\begin{array}{c}100.0 \\
0 \\
\end{array}$ & 94.98 & $\begin{array}{c}100.0 \\
0 \\
\end{array}$ & $\begin{array}{c}100.0 \\
0 \\
\end{array}$ & 98.93 & 0 \\
\hline 15 & 95.00 & $\begin{array}{c}93.2 \\
3\end{array}$ & $\begin{array}{c}89.3 \\
1\end{array}$ & $\begin{array}{c}84.6 \\
4\end{array}$ & $\begin{array}{c}80.6 \\
4\end{array}$ & $\begin{array}{c}88.5 \\
6\end{array}$ & VS & 98.64 & $\begin{array}{c}100.0 \\
0\end{array}$ & $\begin{array}{c}100.0 \\
0\end{array}$ & 99.64 & $\begin{array}{c}100.0 \\
0\end{array}$ & 99.66 & 0 \\
\hline 16 & 96.65 & $\begin{array}{c}94.2 \\
0\end{array}$ & $\begin{array}{c}96.8 \\
5\end{array}$ & $\begin{array}{c}80.6 \\
5\end{array}$ & $\begin{array}{c}83.6 \\
5\end{array}$ & $\begin{array}{c}90.4 \\
0\end{array}$ & 0 & 98.54 & 99.84 & 99.98 & $\begin{array}{c}100.0 \\
0\end{array}$ & $\begin{array}{c}100.0 \\
0\end{array}$ & 99.67 & O \\
\hline 17 & 94.15 & $\begin{array}{c}90.1 \\
5 \\
\end{array}$ & $\begin{array}{c}84.1 \\
5 \\
\end{array}$ & $\begin{array}{c}80.1 \\
9 \\
\end{array}$ & $\begin{array}{c}80.8 \\
5 \\
\end{array}$ & $\begin{array}{c}85.9 \\
0 \\
\end{array}$ & VS & 99.98 & 99.50 & $\begin{array}{c}100.0 \\
0\end{array}$ & 99.87 & $\begin{array}{c}100.0 \\
0\end{array}$ & 99.87 & 0 \\
\hline 18 & 98.85 & $\begin{array}{c}97.0 \\
0 \\
\end{array}$ & $\begin{array}{c}93.2 \\
1 \\
\end{array}$ & $\begin{array}{c}90.6 \\
5 \\
\end{array}$ & $\begin{array}{c}87.5 \\
0 \\
\end{array}$ & $\begin{array}{c}93.4 \\
4 \\
\end{array}$ & 0 & 99.65 & $\begin{array}{c}100.0 \\
0\end{array}$ & $\begin{array}{c}100.0 \\
0\end{array}$ & $\begin{array}{c}100.0 \\
0\end{array}$ & $\begin{array}{c}100.0 \\
0\end{array}$ & 99.93 & O \\
\hline 19 & 94.05 & $\begin{array}{c}89.1 \\
5 \\
\end{array}$ & $\begin{array}{c}81.0 \\
0 \\
\end{array}$ & $\begin{array}{c}80.1 \\
5 \\
\end{array}$ & $\begin{array}{c}80.0 \\
0 \\
\end{array}$ & $\begin{array}{c}84.8 \\
7 \\
\end{array}$ & $S$ & $\begin{array}{c}100.0 \\
0\end{array}$ & 95.85 & $\begin{array}{c}100.0 \\
0\end{array}$ & $\begin{array}{c}100.0 \\
0\end{array}$ & $\begin{array}{c}100.0 \\
0\end{array}$ & 99.17 & 0 \\
\hline 20 & 90.85 & $\begin{array}{c}84.1 \\
8\end{array}$ & $\begin{array}{c}80.8 \\
5\end{array}$ & $\begin{array}{c}76.8 \\
4\end{array}$ & $\begin{array}{c}78.8 \\
4\end{array}$ & $\begin{array}{c}82.3 \\
1\end{array}$ & $S$ & 98.15 & 98.85 & 99.15 & $\begin{array}{c}100.0 \\
0\end{array}$ & $\begin{array}{c}100.0 \\
0\end{array}$ & 99.23 & O \\
\hline 21 & 99.65 & $\begin{array}{c}99.6 \\
0\end{array}$ & $\begin{array}{c}96.7 \\
1\end{array}$ & $\begin{array}{c}90.2 \\
6\end{array}$ & $\begin{array}{c}88.5 \\
4\end{array}$ & $\begin{array}{c}94.9 \\
5\end{array}$ & 0 & 99.36 & 99.89 & $\begin{array}{c}100.0 \\
0\end{array}$ & 99.95 & $\begin{array}{c}100.0 \\
0\end{array}$ & 99.84 & O \\
\hline
\end{tabular}




\begin{tabular}{|c|c|c|c|c|c|c|c|c|c|c|c|c|c|c|}
\hline 22 & 92.01 & $\begin{array}{c}86.0 \\
5 \\
\end{array}$ & $\begin{array}{c}80.1 \\
5 \\
\end{array}$ & $\begin{array}{c}78.1 \\
5 \\
\end{array}$ & $\begin{array}{c}76.8 \\
5 \\
\end{array}$ & $\begin{array}{c}82.6 \\
4 \\
\end{array}$ & $S$ & $\begin{array}{c}100.0 \\
0 \\
\end{array}$ & $\begin{array}{c}100.0 \\
0 \\
\end{array}$ & $\begin{array}{c}100.0 \\
0 \\
\end{array}$ & $\begin{array}{c}100.0 \\
0 \\
\end{array}$ & $\begin{array}{c}100.0 \\
0 \\
\end{array}$ & $\begin{array}{c}100.0 \\
0\end{array}$ & 0 \\
\hline 23 & 95.23 & $\begin{array}{c}90.5 \\
0\end{array}$ & $\begin{array}{c}86.1 \\
5\end{array}$ & $\begin{array}{c}84.6 \\
5\end{array}$ & $\begin{array}{c}89.5 \\
1\end{array}$ & $\begin{array}{c}89.2 \\
1 \\
\end{array}$ & VS & 99.98 & $\begin{array}{c}100.0 \\
0\end{array}$ & $\begin{array}{c}100.0 \\
0\end{array}$ & $\begin{array}{c}100.0 \\
0\end{array}$ & $\begin{array}{c}100.0 \\
0\end{array}$ & $\begin{array}{c}100.0 \\
0\end{array}$ & 0 \\
\hline 24 & 94.85 & $\begin{array}{c}85.8 \\
4\end{array}$ & $\begin{array}{c}82.1 \\
5\end{array}$ & $\begin{array}{c}80.1 \\
5\end{array}$ & $\begin{array}{c}79.8 \\
5\end{array}$ & $\begin{array}{c}84.5 \\
7\end{array}$ & $S$ & $\begin{array}{c}100.0 \\
0\end{array}$ & 98.95 & $\begin{array}{c}100.0 \\
0\end{array}$ & $\begin{array}{c}100.0 \\
0\end{array}$ & $\begin{array}{c}100.0 \\
0\end{array}$ & 99.79 & 0 \\
\hline 25 & 94.56 & $\begin{array}{c}95.0 \\
0\end{array}$ & $\begin{array}{c}93.3 \\
2\end{array}$ & $\begin{array}{c}86.4 \\
5\end{array}$ & $\begin{array}{c}86.1 \\
0\end{array}$ & $\begin{array}{c}91.0 \\
9\end{array}$ & 0 & 99.98 & 98.75 & 99.94 & 99.86 & $\begin{array}{c}100.0 \\
0\end{array}$ & 99.71 & 0 \\
\hline 26 & 99.65 & $\begin{array}{c}90.2 \\
4\end{array}$ & $\begin{array}{c}86.6 \\
1\end{array}$ & $\begin{array}{c}80.6 \\
3\end{array}$ & $\begin{array}{c}81.6 \\
5\end{array}$ & $\begin{array}{c}87.7 \\
6\end{array}$ & VS & $\begin{array}{c}100.0 \\
0\end{array}$ & 98.00 & $\begin{array}{c}100.0 \\
0\end{array}$ & $\begin{array}{c}100.0 \\
0\end{array}$ & $\begin{array}{c}100.0 \\
0\end{array}$ & 99.60 & 0 \\
\hline 27 & 99.00 & $\begin{array}{c}94.6 \\
5 \\
\end{array}$ & $\begin{array}{c}93.6 \\
5 \\
\end{array}$ & $\begin{array}{c}89.6 \\
5 \\
\end{array}$ & $\begin{array}{c}84.6 \\
5\end{array}$ & $\begin{array}{c}92.3 \\
2\end{array}$ & 0 & $\begin{array}{c}100.0 \\
0\end{array}$ & 99.95 & $\begin{array}{c}100.0 \\
0\end{array}$ & $\begin{array}{c}100.0 \\
0 \\
\end{array}$ & $\begin{array}{c}100.0 \\
0\end{array}$ & 99.99 & 0 \\
\hline 28 & 94.66 & $\begin{array}{c}90.2 \\
5\end{array}$ & $\begin{array}{c}86.8 \\
5\end{array}$ & $\begin{array}{c}87.0 \\
0\end{array}$ & $\begin{array}{c}84.7 \\
5\end{array}$ & $\begin{array}{c}88.7 \\
0\end{array}$ & VS & $\begin{array}{c}100.0 \\
0\end{array}$ & $\begin{array}{c}100.0 \\
0\end{array}$ & $\begin{array}{c}100.0 \\
0\end{array}$ & $\begin{array}{c}100.0 \\
0\end{array}$ & $\begin{array}{c}100.0 \\
0\end{array}$ & $\begin{array}{c}100.0 \\
0\end{array}$ & 0 \\
\hline 29 & 99.84 & $\begin{array}{c}98.6 \\
5\end{array}$ & $\begin{array}{c}94.6 \\
5\end{array}$ & $\begin{array}{c}91.6 \\
5\end{array}$ & $\begin{array}{c}90.0 \\
0\end{array}$ & $\begin{array}{c}94.9 \\
6\end{array}$ & 0 & 98.90 & $\begin{array}{c}100.0 \\
0\end{array}$ & $\begin{array}{c}100.0 \\
0\end{array}$ & $\begin{array}{c}100.0 \\
0\end{array}$ & $\begin{array}{c}100.0 \\
0\end{array}$ & 99.78 & 0 \\
\hline 30 & 90.15 & $\begin{array}{c}89.1 \\
5\end{array}$ & $\begin{array}{c}80.1 \\
5\end{array}$ & $\begin{array}{c}78.1 \\
5\end{array}$ & $\begin{array}{c}90.2 \\
1\end{array}$ & $\begin{array}{c}85.5 \\
6\end{array}$ & VS & $\begin{array}{c}100.0 \\
0\end{array}$ & $\begin{array}{c}100.0 \\
0\end{array}$ & $\begin{array}{c}100.0 \\
0\end{array}$ & $\begin{array}{c}100.0 \\
0\end{array}$ & $\begin{array}{c}100.0 \\
0\end{array}$ & $\begin{array}{c}100.0 \\
0\end{array}$ & 0 \\
\hline 31 & 94.00 & $\begin{array}{c}90.6 \\
5 \\
\end{array}$ & $\begin{array}{c}89.8 \\
4 \\
\end{array}$ & $\begin{array}{c}82.1 \\
5 \\
\end{array}$ & $\begin{array}{c}80.2 \\
5 \\
\end{array}$ & $\begin{array}{c}87.3 \\
8 \\
\end{array}$ & VS & $\begin{array}{c}100.0 \\
0 \\
\end{array}$ & $\begin{array}{c}100.0 \\
0\end{array}$ & $\begin{array}{c}100.0 \\
0 \\
\end{array}$ & $\begin{array}{c}100.0 \\
0\end{array}$ & $\begin{array}{c}100.0 \\
0 \\
\end{array}$ & $\begin{array}{c}100.0 \\
0\end{array}$ & 0 \\
\hline 32 & 95.15 & $\begin{array}{c}91.8 \\
5\end{array}$ & $\begin{array}{c}84.1 \\
5\end{array}$ & $\begin{array}{c}80.1 \\
5\end{array}$ & $\begin{array}{c}80.7 \\
5\end{array}$ & $\begin{array}{c}86.4 \\
1\end{array}$ & VS & $\begin{array}{c}100.0 \\
0\end{array}$ & 98.26 & $\begin{array}{c}100.0 \\
0\end{array}$ & $\begin{array}{c}100.0 \\
0\end{array}$ & $\begin{array}{c}100.0 \\
0\end{array}$ & 99.65 & 0 \\
\hline 33 & 96.95 & $\begin{array}{c}90.6 \\
5\end{array}$ & $\begin{array}{c}86.0 \\
0\end{array}$ & $\begin{array}{c}82.8 \\
5\end{array}$ & $\begin{array}{c}80.6 \\
5\end{array}$ & $\begin{array}{c}87.4 \\
2\end{array}$ & VS & $\begin{array}{c}100.0 \\
0\end{array}$ & $\begin{array}{c}100.0 \\
0\end{array}$ & $\begin{array}{c}100.0 \\
0\end{array}$ & $\begin{array}{c}100.0 \\
0\end{array}$ & $\begin{array}{c}100.0 \\
0\end{array}$ & $\begin{array}{c}100.0 \\
0\end{array}$ & 0 \\
\hline 34 & 98.85 & $\begin{array}{c}90.0 \\
0\end{array}$ & $\begin{array}{c}86.6 \\
4\end{array}$ & $\begin{array}{c}89.8 \\
4\end{array}$ & $\begin{array}{c}85.9 \\
5\end{array}$ & $\begin{array}{c}90.2 \\
6\end{array}$ & 0 & 99.98 & 99.98 & $\begin{array}{c}100.0 \\
0\end{array}$ & $\begin{array}{c}100.0 \\
0\end{array}$ & $\begin{array}{c}100.0 \\
0\end{array}$ & 99.99 & 0 \\
\hline 35 & 96.15 & $\begin{array}{c}84.1 \\
5\end{array}$ & $\begin{array}{c}80.1 \\
5\end{array}$ & $\begin{array}{c}82.1 \\
5\end{array}$ & $\begin{array}{c}84.8 \\
5\end{array}$ & $\begin{array}{c}85.4 \\
9\end{array}$ & VS & $\begin{array}{c}100.0 \\
0\end{array}$ & $\begin{array}{c}100.0 \\
0\end{array}$ & $\begin{array}{c}100.0 \\
0\end{array}$ & $\begin{array}{c}100.0 \\
0\end{array}$ & $\begin{array}{c}100.0 \\
0\end{array}$ & $\begin{array}{c}100.0 \\
0\end{array}$ & 0 \\
\hline 36 & 94.15 & $\begin{array}{c}83.1 \\
2 \\
\end{array}$ & $\begin{array}{c}80.9 \\
5 \\
\end{array}$ & $\begin{array}{c}76.8 \\
5 \\
\end{array}$ & $\begin{array}{c}79.8 \\
4 \\
\end{array}$ & $\begin{array}{c}82.9 \\
8 \\
\end{array}$ & $\mathrm{~S}$ & $\begin{array}{c}100.0 \\
0 \\
\end{array}$ & $\begin{array}{c}100.0 \\
0 \\
\end{array}$ & $\begin{array}{c}100.0 \\
0 \\
\end{array}$ & $\begin{array}{c}100.0 \\
0 \\
\end{array}$ & $\begin{array}{c}100.0 \\
0\end{array}$ & $\begin{array}{c}100.0 \\
0\end{array}$ & 0 \\
\hline 37 & 99.00 & $\begin{array}{c}96.6 \\
5 \\
\end{array}$ & $\begin{array}{c}94.6 \\
1 \\
\end{array}$ & $\begin{array}{c}89.5 \\
1 \\
\end{array}$ & $\begin{array}{c}89.9 \\
5 \\
\end{array}$ & $\begin{array}{c}93.9 \\
4 \\
\end{array}$ & 0 & $\begin{array}{c}100.0 \\
0\end{array}$ & 99.84 & $\begin{array}{c}100.0 \\
0 \\
\end{array}$ & $\begin{array}{c}100.0 \\
0 \\
\end{array}$ & $\begin{array}{c}100.0 \\
0\end{array}$ & 99.97 & 0 \\
\hline 38 & 98.00 & $\begin{array}{c}90.0 \\
0\end{array}$ & $\begin{array}{c}84.1 \\
5\end{array}$ & $\begin{array}{c}80.1 \\
5\end{array}$ & $\begin{array}{c}80.7 \\
5\end{array}$ & $\begin{array}{c}86.6 \\
1\end{array}$ & VS & 96.84 & $\begin{array}{c}100.0 \\
0\end{array}$ & 99.94 & 99.00 & $\begin{array}{c}100.0 \\
0\end{array}$ & 99.16 & 0 \\
\hline 39 & 99.85 & $\begin{array}{c}98.6 \\
5 \\
\end{array}$ & $\begin{array}{c}98.0 \\
0 \\
\end{array}$ & $\begin{array}{c}94.6 \\
1 \\
\end{array}$ & $\begin{array}{c}90.1 \\
0 \\
\end{array}$ & $\begin{array}{c}96.2 \\
4 \\
\end{array}$ & 0 & 99.98 & 98.97 & $\begin{array}{c}100.0 \\
0 \\
\end{array}$ & 99.02 & $\begin{array}{c}100.0 \\
0 \\
\end{array}$ & 99.59 & 0 \\
\hline 40 & 95.84 & $\begin{array}{c}90.2 \\
5\end{array}$ & $\begin{array}{c}84.1 \\
5 \\
\end{array}$ & $\begin{array}{c}85.6 \\
5 \\
\end{array}$ & $\begin{array}{c}84.1 \\
5 \\
\end{array}$ & $\begin{array}{c}88.0 \\
1 \\
\end{array}$ & VS & 99.98 & $\begin{array}{c}100.0 \\
0\end{array}$ & 99.98 & $\begin{array}{c}100.0 \\
0\end{array}$ & $\begin{array}{c}100.0 \\
0\end{array}$ & 99.99 & 0 \\
\hline 41 & 98.65 & $\begin{array}{c}99.8 \\
4 \\
\end{array}$ & $\begin{array}{c}94.6 \\
1 \\
\end{array}$ & $\begin{array}{c}91.8 \\
5 \\
\end{array}$ & $\begin{array}{c}89.0 \\
7 \\
\end{array}$ & $\begin{array}{c}94.8 \\
0\end{array}$ & 0 & $\begin{array}{c}100.0 \\
0 \\
\end{array}$ & $\begin{array}{c}100.0 \\
0 \\
\end{array}$ & $\begin{array}{c}100.0 \\
0 \\
\end{array}$ & $\begin{array}{c}100.0 \\
0\end{array}$ & $\begin{array}{c}100.0 \\
0 \\
\end{array}$ & $\begin{array}{c}100.0 \\
0\end{array}$ & 0 \\
\hline 42 & 98.56 & $\begin{array}{c}99.0 \\
0\end{array}$ & $\begin{array}{c}94.9 \\
5 \\
\end{array}$ & $\begin{array}{c}93.7 \\
5\end{array}$ & $\begin{array}{c}90.2 \\
3\end{array}$ & $\begin{array}{c}95.3 \\
0\end{array}$ & 0 & $\begin{array}{c}100.0 \\
0\end{array}$ & $\begin{array}{c}100.0 \\
0\end{array}$ & $\begin{array}{c}100.0 \\
0\end{array}$ & $\begin{array}{c}100.0 \\
0\end{array}$ & $\begin{array}{c}100.0 \\
0\end{array}$ & $\begin{array}{c}100.0 \\
0\end{array}$ & 0 \\
\hline 43 & 94.96 & $\begin{array}{c}90.6 \\
5\end{array}$ & $\begin{array}{c}84.8 \\
5\end{array}$ & $\begin{array}{c}83.8 \\
5\end{array}$ & $\begin{array}{c}84.1 \\
5\end{array}$ & $\begin{array}{c}87.6 \\
9\end{array}$ & VS & 98.94 & 99.98 & $\begin{array}{c}100.0 \\
0\end{array}$ & $\begin{array}{c}100.0 \\
0\end{array}$ & $\begin{array}{c}100.0 \\
0\end{array}$ & 99.78 & 0 \\
\hline 44 & 90.99 & $\begin{array}{c}91.2 \\
0\end{array}$ & $\begin{array}{c}89.8 \\
4\end{array}$ & $\begin{array}{c}86.7 \\
5\end{array}$ & $\begin{array}{c}80.5 \\
1\end{array}$ & $\begin{array}{c}87.8 \\
6\end{array}$ & VS & $\begin{array}{c}100.0 \\
0\end{array}$ & 99.94 & $\begin{array}{c}100.0 \\
0\end{array}$ & $\begin{array}{c}100.0 \\
0\end{array}$ & $\begin{array}{c}100.0 \\
0\end{array}$ & 99.99 & 0 \\
\hline 45 & 94.85 & $\begin{array}{c}95.0 \\
0\end{array}$ & $\begin{array}{c}93.5 \\
1\end{array}$ & $\begin{array}{c}94.8 \\
2\end{array}$ & $\begin{array}{c}89.6 \\
4\end{array}$ & $\begin{array}{c}93.5 \\
6\end{array}$ & 0 & 99.94 & $\begin{array}{c}100.0 \\
0\end{array}$ & $\begin{array}{c}100.0 \\
0\end{array}$ & 99.84 & $\begin{array}{c}100.0 \\
0\end{array}$ & 99.96 & 0 \\
\hline 46 & 96.85 & $\begin{array}{c}90.6 \\
6\end{array}$ & $\begin{array}{c}86.8 \\
4\end{array}$ & $\begin{array}{c}86.0 \\
5\end{array}$ & $\begin{array}{c}83.6 \\
1\end{array}$ & $\begin{array}{c}88.8 \\
0\end{array}$ & VS & 99.89 & 99.98 & $\begin{array}{c}100.0 \\
0\end{array}$ & 95.84 & $\begin{array}{c}100.0 \\
0\end{array}$ & 99.14 & 0 \\
\hline 47 & 97.84 & $\begin{array}{c}91.0 \\
0\end{array}$ & $\begin{array}{c}89.0 \\
5\end{array}$ & $\begin{array}{c}86.1 \\
4\end{array}$ & $\begin{array}{c}85.1 \\
6\end{array}$ & $\begin{array}{c}89.8 \\
4\end{array}$ & VS & $\begin{array}{c}100.0 \\
0\end{array}$ & 99.84 & 99.01 & $\begin{array}{c}100.0 \\
0\end{array}$ & $\begin{array}{c}100.0 \\
0\end{array}$ & 99.77 & 0 \\
\hline
\end{tabular}




\begin{tabular}{c|c|c|c|c|c|c|c|c|c|c|c|c|c|c}
48 & 96.84 & $\begin{array}{c}92.8 \\
6\end{array}$ & $\begin{array}{c}91.0 \\
0\end{array}$ & $\begin{array}{c}86.8 \\
1\end{array}$ & $\begin{array}{c}84.1 \\
6\end{array}$ & $\begin{array}{c}90.3 \\
3\end{array}$ & 0 & 99.97 & 99.85 & $\begin{array}{c}100.0 \\
0\end{array}$ & 98.84 & $\begin{array}{c}100.0 \\
0\end{array}$ & 99.73 & 0 \\
\hline 49 & 95.00 & $\begin{array}{c}90.5 \\
2\end{array}$ & $\begin{array}{c}89.1 \\
5\end{array}$ & $\begin{array}{c}87.1 \\
9\end{array}$ & $\begin{array}{c}83.1 \\
5\end{array}$ & $\begin{array}{c}89.0 \\
0\end{array}$ & VS & 98.85 & 99.98 & $\begin{array}{c}100.0 \\
0\end{array}$ & 99.95 & $\begin{array}{c}100.0 \\
0\end{array}$ & 99.76 & 0 \\
\hline 50 & 94.65 & $\begin{array}{c}90.6 \\
5\end{array}$ & $\begin{array}{c}84.1 \\
5\end{array}$ & $\begin{array}{c}83.2 \\
5\end{array}$ & $\begin{array}{c}84.6 \\
5\end{array}$ & $\begin{array}{c}87.4 \\
7\end{array}$ & VS & 98.85 & 98.84 & 98.98 & $\begin{array}{c}100.0 \\
0\end{array}$ & $\begin{array}{c}100.0 \\
0\end{array}$ & 99.33 & 0 \\
\hline \hline
\end{tabular}

Table 2.2. Level of Class Attendance Percentage Average on the months before and after using the SAM app.

\begin{tabular}{|c|c|c|c|c|c|c|c|}
\hline \multirow[t]{2}{*}{ Scale } & \multirow[t]{2}{*}{ Descriptors } & \multicolumn{3}{|c|}{$\begin{array}{l}\text { Before using the SAM App } \\
\text { (June } 2019 \text { - October 2019) }\end{array}$} & \multicolumn{3}{|c|}{$\begin{array}{l}\text { After Using the SAM App } \\
\text { (Nov. 2019 - March 2020) }\end{array}$} \\
\hline & & Frequency & $\%$ & Rank & Frequency & $\%$ & Rank \\
\hline $90-100$ & Outstanding $(\mathrm{O})$ & 18 & $36 \%$ & 2 & 50 & $100 \%$ & 1 \\
\hline $85-89$ & Very Satisfactory (VS) & 27 & $54 \%$ & 1 & 0 & $0 \%$ & - \\
\hline $80-84$ & Satisfactory (S) & 5 & $10 \%$ & 3 & 0 & $0 \%$ & - \\
\hline $75-79$ & Fairy Satisfactory (FS) & 0 & $0 \%$ & - & 0 & $0 \%$ & - \\
\hline below 75 & Did not meet expectation (DNME) & 0 & $0 \%$ & - & 0 & $0 \%$ & - \\
\hline & TOTAL & 50 & $100 \%$ & & 50 & $100 \%$ & \\
\hline
\end{tabular}

Table 2.1 and Table 2.2 disclosed the data and the level of class attendance percentage average on the months before and after using the SAM app. Data revealed that in the general percentage average on the months (June 2019-October 2019) before using the SAM app, majority of the classes with a frequency of $27(54 \%)$ have a very satisfactory attendance that falls between the scale of 85-89 per cent; follows by 18 (36\%) classes with an outstanding attendance within the range of the scale $90-100$ percent, and the remaining $5(10 \%)$ classes have a satisfactory attendance within the range of the scale 80-84 percent. On the other hand, as observed in the data, the general percentage average on the months (November 2019 - March 2020) after using the SAM app shows that all $50(100 \%)$ classes have an Outstanding Attendance that falls within the range of the scale $90-100$ percent.

Based on the data, it can be preliminarily concluded that with the use of Scan Attendance Manager app using Quick Response Code, the attendance of the class will be improved considering that it notifies parents with the real-time report that makes them engage. According to Epstein, J.L. \& Sheldon, S.B. (2004), students with engaged parents report fewer school days missed in general. Two-way communication between guardians and educators commits students to daily attendance and raises class participation levels.

Table 3. Significant Difference on the weighted average class attendance percentage between the months before and after using the SAM app

\begin{tabular}{|c|c|c|c|c|}
\hline & $\begin{array}{c}\text { Before using the SAM } \\
\text { app } \\
X_{1}\end{array}$ & $\begin{array}{c}\text { After Using the Sam } \\
\text { App } \\
X_{2}\end{array}$ & $(\mathrm{X} 1 \text {-mean })^{2}$ & $(\mathrm{X} 2 \text {-mean })^{2}$ \\
\hline SUM & 4460.92 & 4984.55 & 594.73 & 9.02 \\
\hline MEAN & 89.22 & 99.69 & & \\
\hline$n$ & 50 & 50 & & \\
\hline Variance & & & 12.14 & 0.18 \\
\hline \multicolumn{5}{|c|}{ Computed $t$} \\
\hline \multicolumn{2}{|r|}{$p$-value } & 0.00000 & & \\
\hline \multicolumn{2}{|r|}{ Critical value } & 1.9845 & & \\
\hline \multicolumn{2}{|r|}{$d f$} & 98 & & \\
\hline \multicolumn{2}{|r|}{ Level of Significance } & 0.05 & & \\
\hline \multicolumn{2}{|r|}{ Result } & Reject Ho & & \\
\hline \multicolumn{2}{|r|}{ Remarks } & Significant & & \\
\hline
\end{tabular}


Table 3 presents the analysis for the Significant difference in the weighted average of the class attendance percentage between the months before and after using the SAM app. Since the computed t value of -21.0963 is greater than the critical value of 1.9845 using 0.05 level of significance at 98 degrees of freedom, the null hypothesis of the study is rejected which means that there is a significant difference between the weighted average class attendance percentage of the months before and after using the SAM app.

With the significant negative result, the data further implies that the weighted average of the class attendance percentage after using the SAM App have contained a more excellent value compared to weighted average before using the SAM app with means of 99.69 and 89.22 respectively. This result gives the further implication that the attendance of the class after the teachers have utilized the SAM application had evidently shown significant improvement; thus the Scan Attendance Manager Application using Quick Response Code is useful not just by providing convenience to teachers, but importantly it virtually eliminates absences.

As already mentioned, SAM application will not just simply check the attendance of the student, because upon scanning their QR code it immediately sends SMS to parents for them to be informed with their child's whereabouts, thus through this method, parents engagement will have a significant impact in responding to eliminating absences. This result was supported by Epstein and Sheldon (2002) wherein they stressed that Family involvement is an integral part of reducing school absenteeism, and schools need to collaborate with families to improve student attendance.

Table 4.1. Data of the five classifications of the Efficacy of the SAM app as perceived by the teachers.

\begin{tabular}{c|c|c|c|c|c|c}
\hline \hline Groups & $\mathbf{N}$ & $\mathbf{\Sigma x}$ & $\mathbf{( \Sigma x})^{\mathbf{2}}$ & $\mathbf{S S}$ & Variance & Mean $\mathbf{x}$ \\
\hline Reliability & 50 & 169.33 & 28673.78 & 10.524 & 0.215 & 3.387 \\
\hline Efficiency & 50 & 184 & 33856.00 & 7.991 & 0.163 & 3.680 \\
\hline Accuracy & 50 & 178.33 & 31802.78 & 8.278 & 0.169 & 3.567 \\
\hline Usability & 50 & 176.33 & 31093.44 & 10.687 & 0.218 & 3.527 \\
\hline Security & 50 & 176 & 30976.00 & 13.369 & 0.273 & 3.520 \\
\hline Total & 250 & 884 & 156402 & 50.849 & 1.038 & \\
\hline \hline
\end{tabular}

Table 4.2. Analysis for the Significant Variance among the five classifications of the Efficacy of the SAM app as perceived by the teachers.

\begin{tabular}{|c|c|c|c|c|c|c|}
\hline Source of Variation & SS & df & MS & $\mathbf{F}$ & P-value & $\begin{array}{c}\text { Critical Value } \\
\text { at } 0.05\end{array}$ \\
\hline Between Groups & 2.216 & 4 & 0.554 & 2.669282 & 0.03288753 & 2.40848837 \\
\hline Within Groups & 50.84888889 & 245 & 0.207546 & & & \\
\hline Total & 53.06488889 & 249 & & & & \\
\hline \multicolumn{7}{|c|}{ Result: Reject Ho } \\
\hline & & Remarks: & Significant & & & \\
\hline
\end{tabular}

Table 4.3. Multiple Comparison using Scheffès Test

\begin{tabular}{l|c|c|c|c|c|c}
\hline \hline \multicolumn{2}{c|}{ Between Treatments } & Mean 1 & Mean 2 & F' & $\begin{array}{c}\text { Scheffès Critical } \\
\text { Value }\end{array}$ & Interpretation \\
\hline Reliability & Efficiency & 3.387 & 3.680 & 10.364 & 9.634 & Significant \\
\hline Reliability & Accuracy & 3.387 & 3.567 & 3.903 & 9.634 & Not Significant \\
\hline Reliability & Usability & 3.387 & 3.527 & 2.361 & 9.634 & Not Significant \\
\hline Reliability & Security & 3.387 & 3.520 & 2.141 & 9.634 & Not Significant \\
\hline
\end{tabular}




\begin{tabular}{l|l|l|l|l|l|l} 
Efficiency & Accuracy & 3.680 & 3.567 & 1.547 & 9.634 & Not Significant \\
\hline Efficiency & Usability & 3.680 & 3.527 & 2.832 & 9.634 & Not Significant \\
\hline Efficiency & Security & 3.680 & 3.520 & 3.084 & 9.634 & Not Significant \\
\hline Accuracy & Usability & 3.567 & 3.527 & 0.193 & 9.634 & Not Significant \\
\hline Accuracy & Security & 3.567 & 3.520 & 0.262 & 9.634 & Not Significant \\
\hline Usability & Security & 3.527 & 3.520 & 0.005 & 9.634 & Not Significant \\
\hline \hline
\end{tabular}

Table 4.1 and Table 4.2 present the significant variance among the five classifications of the Efficacy of the Scan Attendance Manager App as perceived by the teachers. It was found out that the computed F value of 2.669282 is greater than the critical value of 2.40848837 using 0.05 level of significance at 4 and 245 degrees of freedom; thus the null hypothesis of the study is rejected which means that there is a significant variance among the five classifications of the Efficacy of the Scan Attendance Manager App as perceived by the teachers.

With the significant variance, the data were then further subjected to multiple comparisons through Scheffès test as reflected in Table 4.1. Out of 10 pairings, 1 was significant. The significant pairing was between Reliability and Efficiency. From the table, it can be noticed that efficiency has prevailed to have the highest value with a mean of 3.68, while reliability has the lowest value with a mean of 3.387. All other pairings were found insignificant. The result further signifies that among the five classifications, teachers have extensively perceived the efficient output that Scan Attendance Manager application could provide in terms of its general function in monitoring class attendance.

\section{Conclusions and Recommendations}

It was concluded that the Scan Attendance Manager is a reliable application wherein teachers could conveniently use to monitor class attendance by simply scanning the QR code embedded to each student's ID. As expected, this application provides efficient data output from detecting absent students to generating reports; thus, it is advisable to use. As all teacher-respondents strongly agree, there is nothing to worry about generating the reports since the data produced by the SAM application is definitely accurate. It was also concluded that the Scan Attendance Manager app is not only useful for classroom attendance; it can also be used to different kind of activities considering that there will be an attendant to monitor. Moreover, the attendance data report was securely stored in the SAM database, and the teachers need nothing to worry about confidentiality since they are the only ones who have access.

There is a significant difference between the weighted average class attendance percentage of the months before and after using the SAM app. It further signifies that the attendance of the class after the teachers have utilized the SAM application had evidently shown significant improvement; thus the Scan Attendance Manager Application using Quick Response Code is useful not just by providing convenience to teachers, but importantly it virtually eliminates absences.

There is a significant variance among the five classifications of the Efficacy of the Scan Attendance Manager App as perceived by the teachers. Among the five classifications, teachers have extensively perceived the efficient output that Scan Attendance Manager could provide in terms of its general function to monitor the class attendance.

Since the result shows positive feedback and proof as to the effectiveness of Scan Attendance Manager application using Quick Response Code, it is highly recommended to all teachers, especially the classroom advisers to install and use the SAM application through their smartphone for a modern alternative way in checking their class attendance. Since the SMS feature of the SAM app costs load when it is opted to send a report to parents, it is recommended to the school administrators to find means to include load budget for the teachers through the School MOOE fund. Parents are also recommended to provide updated contact numbers to teachers so they will receive notification from the school. Parents should always reach the class adviser and do follow up on the progress made by their children in school as it was proven that their engagement might also help to lessen absenteeism. Students should always abide in school policy, especially with regards to school attendance. It is recommended to the future researchers to conduct a replicate study to address other concerns and variables that may affect the efficacy of Scan Attendance Manager application using Quick Response code. 


\section{References}

[1] Batas Pambansa Blg. 232. Retrieved from https://www.lawphil.net/statutes/bataspam/bp1982/bp_232_1982.html

[2] Cherry, K. (2019). Self-determination theory and motivation. Retrieved from https://www.verywellmind.com/what-is-selfdetermination-theory-2795387

[3] Epstein, J.L., \& Sheldon, S. B. (2002). Present and accounted for: Improving student attendance through family and community involvement. Journal of Research, 95(5), 308-318. Retrieved https://oxfordre.com/socialwork/view/10.1093/acrefore/9780199975839.001.0001/acrefore-9780199975839-e-1227

[4] Epstein, J.L., \& Sheldon, S.B. (2004). Getting Students to School: Using Family and Community Involvement to Reduce Chronic Absenteeism. School Community Journal, 14, pp 39-56. Retrieved from https://www.waterford.org/education/how-parent-involvmentleads-to-student-success/

[5] Farhan, A. (2015). Students attendance monitoring. Retrieved on June 24, 2019, from https://jetir.org

[6] Gayatri, R. (n.d.). Attendance monitoring system. Retrieved on June 27, 2019, from https://ezine articles.com/Gayatri-radhakrishnanattendancemonitoringsystem

[7] GreatSchools Staff (2011). Why attendance matters? Retrieved from https://www.greatschools.org/gk/articles/school-attendanceissues/

[8] Lucido (2014). Attendance monitoring system as time log. Retrieved from https://www.study mode.com/Attendance-monitoring-system

[9] Maleriado, M.A.C. \& Carreon, J. R. (2018). The features of quick response (qr) code as an attendance monitoring system: Its acceptability and implications. Retrieved on June 27, 2019, from https://newyorkessays.com/essay-attendance-monitoring-system

[10] Meador, D. (2017). Why school attendance matters and strategies to improve it. Retrieved from https://www.thoughtco.com/why-school-attendance-matters-3194437.

[11] Molina, C.J. (2018). VIRAL: Techy teacher tracks students class attendance via QR codes. Retrieved from https://technology.inquirer.net/77033/viral-techy-teacher-tracks-students-class-attendance-via-qr-codes

[12] Person, P. (2015). Motivational theory. Retrieved on June 24, 2019, from https://www.google.com/article+monitoring+attendance

[13] Republic Act No. 672. Philippine laws, statutes, codes \& issuances. Retrieved from https://laws.chanrobles.com/republicacts/7_republicacts.php?id=675

[14] Roshon, B. (2015). Importance of student attendance. Retrieved from https://www. relliterature.com/Roshon-bradley-importance-ofattendance

[15] Theory of Work Adjustment (n.d). Retrieved from https://goo.gl/jkXVfu

[16] Wood, R. (2015). Best practices to improve attendance. Retrieved, from https://www.google.com/wood/best-practices-to-improveattendance 